\title{
NEW DISTRIBUTIONAL DATA ON BRYOPHYTES OF POLAND AND SLOVAKIA, 8
}

\author{
Piotr Górski, Grzegorz Vončina, Michą Smoczyk, Henryk Klama, Rudolf Šoltés, \\ Marcin Wilhelm, Magdalena RutKowska
}

Editors of the column: Piotr Górski, AnNa Rusińska

Series "New distributional data on bryophytes of Poland (and Slovakia)" is a scientific bulletin of Bryological Section of Polish Botanical Society

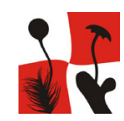

P. Górski, Department of Botany, Poznań University of Life Sciences, Wojska Polskiego 71 C, 60-625 Poznań, Poland, e-mail: peter@up.poznan.pl

H. Klama, Institute of Environmental Protection and Engineering, University of Bielsko-Biała, Willowa 2, 43-309 Bielsko-Biała, Poland, e-mail: hklama@ath.bielsko.pl

A. Rusińska, Natural History Collections, Adam Mickiewicz University, Umultowska 89, 61-614 Poznań, Poland, e-mail: annarus@amu.edu.pl

M. Rutkowska, Department of Biochemistry, Faculty of Biology, University of Szczecin, Wąska 13, 71-415 Szczecin, Poland, e-mail: magdarut27@gmail.com

M. Smoczyk, Wojska Polskiego 30/5, 69-110 Rzepin, Poland, e-mail: msmoczyk@wp.pl

R. Šoltés, 19 Podtatranská, SK 05801 Poprad, Slovakia, e-mail: rudolf.soltes@gmail.com

G. Vončina, Pieniny National Park, Jagiellońska 107 B, 34-450 Krościenko nad Dunajcem, Poland, e-mail: gvoncina@poczta.onet.pl

M. Wilhelm, Department of Geobotany and Plant Taxonomy, Faculty of Biology, University of Szczecin, Wąska 13, 71-415 Szczecin, Poland, e-mail: junin@univ.szczecin.pl

(Received: October 25, 2016. Accepted: December 5, 2016)

\begin{abstract}
Aвstract. This work presents a list of localities for the following species: Anastrophyllum michauxii, Campylopus introflexus, Cephaloziella elachista, Cinclidotus fontinaloides, Cololejeunea calcarea, Dicranum viride, Didymodon spadiceus, Fissidens dubius var. mucronatus, Fossombronia wondraczekii, Fuscocephaloziopsis macrostachya, Hypnum cupressiforme var. subjulaceum, Lophozia ascendens, Mesoptychia heterocolpos, Nowellia curvifolia, Rhytidiadelphus loreus, Saccobasis polita, and Trichocolea tomentella.
\end{abstract}

\section{Anastrophyllum michauxii (F. Weber) H. Buch}

Author: P. GóRSKI

Slovakia, Belianske Tatra Mountains: MGRS 34UDV4256, Západné Belianske Tatry, Tristarská dolina valley, middle part of Złoty Żleb gully, $49.26010^{\circ} \mathrm{N}, 20.20949^{\circ} \mathrm{E}, 49.26019^{\circ} \mathrm{N}, 20.20935^{\circ} \mathrm{E}$, alt. $1225 \mathrm{~m}$ above sea level (a.s.1.), $1230 \mathrm{~m}$ a.s.l., decaying log, leg., det. P. Górski, 7.11.2015 (POZNB 2054, 2055); High TATRA MTs: MGRS 34UDV3852, Javorinské Tatry, Javorová dolina valley, between the Javorinka and Cierny potok streams, $49.21903^{\circ} \mathrm{N}$, $20.16166^{\circ} \mathrm{E}$, alt. $1335 \mathrm{~m}$ a.s.l., decaying log in Plagiothecio-Piceetum spruce forest, leg., det. P. Górski, 
21.09.2015 (POZNB 2052); MGRS 34UDV2647, Skupina Kriváňa, Kôprová dolina valley, lower part of Kotlina Krywańskie Koryto, 'Niedźwiedzia Perć', $49.17425^{\circ} \mathrm{N}, 19.98595^{\circ} \mathrm{E}, 49.17363^{\circ} \mathrm{N}, 19.98477^{\circ} \mathrm{E}$, alt. $1370 \mathrm{~m}$ a.s.l., $1380 \mathrm{~m}$ a.s.l., decaying log, leg., det. P. Górski, 16.09.2015 (POZNB 2050, 2053); WeSTeRN TAtra Mts: MGRS 34UDV0843, Masív Baranca a Rázsochy, lower part of Trnovská dolina valley, decaying $\log$ near stream, $49.13597^{\circ} \mathrm{N}, 19.74236^{\circ} \mathrm{E}$, alt. $895 \mathrm{~m}$ a.s.l. (new minimum of the species in the Tatra Mts.), leg., det. P. Górski, 19.09.2015 (POZNB 2051).

Characteristics of the distribution of Anastrophyllum michauxii in the Tatra Mts have been recently presented by GóRSKI (2016). This study presents another six localities of this plant from the Belianske, High, and Western Tatra Mts. One of the localities is the new altitudinal minimum of the liverwort in the Tatra Mts (895 $\mathrm{m}$ a.s.1.). Thus far, the lowest locality of $A$. michauxii was recorded at $900 \mathrm{~m}$ a.s.l. (DUDA \& VÁŇA 1984). Altogether, throughout the entire Tatra Mts, this liverwort grows in 47 localities (GóRSKI \& VÁŇA 2014, GóRSKI 2016).

\section{Campylopus introflexus (Hedw.) Brid.}

Authors: M. Wilhelm, M. RutKowska

ATMOS Ba-09: NW Poland, West Pomerania (Pomorze Zachodnie), Trzebiatowskie coast (Wybrzeże Trzebiatowskie), West Pomerania Province, Kołobrzeg County, Kołobrzeg commune, Dźwirzyno village at the Resko canal, $54.15356^{\circ} \mathrm{N}, 15.39111^{\circ} \mathrm{E}$, sandy soil at the edge of white dune with Elymo-Ammophiletum arenariae, leg., det. M. Wilhelm, 2.04.2014 (SZUB); ATMOS Ba-27: NW Poland, West Pomerania, Gryficka Plain (Równina Gryficka), West Pomerania Province, Gryfice County, Gryfice commune, Modlimowo-Grądy peat bog near Przybiernówko (the socalled 'Wielkie Smogorze'), $53.98078^{\circ} \mathrm{N}, 15.14681^{\circ} \mathrm{E}$, dried peat overgrown with birch in the cutting area of peat work, leg., det. M. Wilhelm, 23.09.2012 (SZUB); ATMOS Ba-44: NW Poland, West Pomerania, Nowogardzka Plain (Równina Nowogardzka), West Pomerania Province, Goleniów County, Przybiernów commune, $53.77806^{\circ} \mathrm{N}, 14.70278^{\circ} \mathrm{E}$, forest section $669 \mathrm{~h}$ of the Rokita Forest Inspectorate, sandy soil at the edge of a Leucobryo-Pinetum plant association in the Grzybnica River valley, leg. M. Rutkowska, 3.04.2014, det. M. Wilhelm (SZUB); ATMOS Ba-73: NW Poland, West Pomerania, Szczecińska Lowland (Nizina Szczecińska), West Pomerania Province, city of Szczecin, 'Wodozbiór' landscape nature protected complex, $53.48944^{\circ} \mathrm{N}, 14.55265^{\circ} \mathrm{E}$, psammophilous grassland along Kredowa Street, leg. M. Rutkowska, 27.03.2012, det. M. Wilhelm (SZUB); ATMOS Ba85: NW Poland, West Pomerania, Goleniowska Plain (Równina Goleniowska), West Pomerania Province, Stargard County, Kobylanka commune, $\sim 4$ km north of Reptowo village, $53.39769^{\circ} \mathrm{N}, 14.83663^{\circ} \mathrm{E}$, a monotonous dense carpet on dried peat where peat digging ceased, leg. M. Rutkowska, 20.03.2016, det. M. Wilhelm (SZUB).

Campylopus introflexus is becoming a more and more common species in West Pomerania (Fudali et al. 2009, GóRSKI 2014, 2015, GóRSKI \& KAPUSTYŃSKI 2015a, WilheLm et al. 2015). The list of the species is still open, as evidenced by the above specifics of its new localities. The given position is an example of a wide range of habitats occupied by $C$. introflexus.

\section{Cephaloziella elachista (J.B. Jack ex Gottsche et Rabenh.) Schiffn.}

Author: P. GóRskI

ATMOS Ab-98: NW Poland, West Pomerania, Sławieńska Plain (Równina Sławieńska), Sławno County, Sławno Forest Inspectorate, 'Janiewickie Bagno' nature reserve, $54.2588^{\circ} \mathrm{N}, 16.72367^{\circ} \mathrm{E}$, in open part of peat bog, leg., det. P. Górski, 28.06.2016 (POZNB). The following liverworts have been reported so far from the 'Janiewickie Bagno' nature reserve: Calypogeia sphagnicola (Arnell et J. Perss.) Warnst. et Loeske, C. neesiana (C. Massal. et Carestia) Müll. Frib., Kurzia pauciflora (Dicks.) Grolle, Lophozia silvicola $\mathrm{H}$. Buch, Mylia anomala (Hook.) Gray, Odontoschisma sphag$n i$ (Dicks.) Dumort., and O. denudatum (Mart.) Dumort. (SZWEYKOWSKI \& KoźLICKA 1969). The presence of these species was confirmed in 2016. Cephaloziella elachista has not been reported previously from that area. Aside from the aforementioned species, the following constitute the flora of the 'Janiewickie Bagno' nature reserve: Cephalozia bicuspidata (L.) Dumort., Fuscocephaloziopsis connivens (Dicks.) Váňa et L. Söderstr. (= Cephalozia connivens (Dicks.) Lindb.), F. lunulifolia (Dumort.) Váňa et L. Söderstr. (= Cephalozia lunulifolia (Dumort.) Dumort.), Lepidozia reptans (L.) Dumort., Lophocolea heterophylla (Schrad.) Dumort., Nowellia curvifolia (Dicks.) Mitt., Pellia epiphylla (L.) Corda, and Riccardia latifrons (Lindb.) Lindb. (P. Górski, unpublished, POZNB).

Localities of Cephaloziella elachista are known from central and northern Poland (SzweYkowski 2006). It seems to be a rare, poor fen species. However, in West Pomerania and western Poland, it is probably more frequent than the published data indicate and overlooked in the field. Since 2000, C. elachista has been recorded by GóRSKI (2013), GóRSKI \& GĄBKA (2015a), and Górski et al. (2015).

\section{Cinclidotus fontinaloides (Hedw.) P. Beauv.}

Author: G. VonČINA

ATMOS Ge-23: S Poland, Beskid Sądecki Range, Małopolska Province, Nowy Sącz County, Łącko commune, Łazy Brzyńskie village, on the sandstone boulders on the bank of the Dunajec River, alt. 332 
$\mathrm{m}$ a.s.l., $49.52658^{\circ} \mathrm{N}, 20.51706^{\circ} \mathrm{E}$, det. G. Vončina, 14.02.2016; S Poland, Beskid Sądecki Range, Małopolska Province, Nowy Sącz County, Łącko commune, village of Zarzecze, Kamieńczyk settlement, on the sandstone boulders in the bed of the Dunajec River, alt. $371 \mathrm{~m}$ a.s.l., $49.53803^{\circ} \mathrm{N}, 20.40992^{\circ} \mathrm{E}$, det. G. Vončina, 13.02.2016; S Poland, Beskid Sądecki Range, Małopolska Province, Nowy Targ County, Ochotnica Dolna commune, village of Tylmanowa, Kamieniec settlement, on the sandstone boulders on the bank of the Dunajec River, alt. $382 \mathrm{~m}$ a.s.1., $49.51386^{\circ} \mathrm{N}$, 20.41783 ${ }^{\circ}$, det. G. Vončina, 13.02.2016; S Poland, Gorce Mountains, Małopolska Province, Nowy Targ County, Ochotnica Dolna commune, village of Tylmanowa-Rzeka, Siwa Górka settlement, on the sandstone boulders on the bank of the Dunajec River, alt. $378 \mathrm{~m}$ a.s.l., $49.51697^{\circ} \mathrm{N}, 20.40311^{\circ} \mathrm{E}$, det. G. Vončina, 14.02.2016; S Poland, Beskid Sądecki Range, Małopolska Province, Nowy Targ County, Ochotnica Dolna commune, village of Tylmanowa, Czeczugi settlement, on the sandstone boulders on the bank of the Dunajec River, alt. $387 \mathrm{~m}$ a.s.1., $49.51064^{\circ} \mathrm{N}$, 20.39806 ${ }^{\circ}$, det. G. Vončina, 13.02.2016; S Poland, Beskid Sądecki Range, Małopolska Province, Nowy Targ County, Ochotnica Dolna commune, village of Tylmanowa, Kłodne next to Popradzki Landscape Park and Nature Reserve Kłodne nad Dunajcem, on the sandstone boulders in the bed of the Dunajec River, alt. $408 \mathrm{~m}$ a.s.1., $49.47542^{\circ} \mathrm{N}, 20.43517^{\circ} \mathrm{E}$, det. G. Vončina, 17.05.2015, conf. A. Stebel and alt. 417 $\mathrm{m}$ a.s.l., $49.47514^{\circ} \mathrm{N}, 20.43642^{\circ} \mathrm{E}$, det. G. Vončina, 17.05.2015.

Cinclidotus fontinaloides is regarded as a threatened species in Poland (category E) and taken under strict protection (ŻARNOWIEC et al. 2004, ORDER... 2014). Milde (1869) published the occurrence of this species as being only from the Lower Silesia (vicinities of Jelenia Góra, Bóbr River, Giant Mountains or Bolesławiec) from the contemporary boundaries of Poland. In the Polish Carpathians, this moss was noted only from the Pieniny Range by ReHMAN (1865), later published by KARCZMARZ (2000). However, once treated as a doubtful species (Stebel et al. 2010), it was found recently (Vončina \& Stebel 2016). The species was observed in the Beskid Sądecki Range at first but nowadays has been confirmed in the Polish Carpathians.

\section{Cololejeunea calcarea (Lib.) Schiffn.}

\section{Author: P. GóRSKI}

Slovakia, High Tatra Mts: 34UDV3752, Skupina Širokej, upper part of the Svištovská dolina valley, $49.22197^{\circ} \mathrm{N}, 20.14102^{\circ} \mathrm{E}$, alt. $1670 \mathrm{~m}$ a.s.l., rock crevices, leg., det. P. Górski, 8.11.2015 (POZNB 2059); Western Tatra Mts: MGRS 34UDV0757, Skupina Osobitej-Bobrovca, Suchá dolina valley, lower part of Široký žlab gully, $49.26642^{\circ} \mathrm{N}, 19.73153^{\circ} \mathrm{E}$, $49.26585^{\circ} \mathrm{N}, 19.72963^{\circ} \mathrm{E}$, alt. $1135 \mathrm{~m}$ a.s.l., 1215 $\mathrm{m}$ a.s.l., calcareous outcrops, leg., det. P. Górski, 24.09.2015 (POZNB 2056, 2058).

Poland, Western Tatra Mts: ATMOS Gd-59, MGRS 34UDV2054, Masyw Czerwonych Wierchów, Kozi Grzbiet ridge (between the Mułowa and Litworowa valleys), $49.23664^{\circ} \mathrm{N}, 19.90863^{\circ} \mathrm{E}$, alt. $1905 \mathrm{~m}$ a.s.l., calcareous outcrops, leg., det. P. Górski, 22.09.2015 (POZNB 2057).

Cololejeunea calcarea is a calciphilous liverwort that grows in the Tatra Mts on calcareous rocks, mostly in the forest belts. As much as $88 \%$ of the localities of this plant have been recorded below $1500 \mathrm{~m}$ a.s.l. Altogether in the Tatra Mts, C. calcarea grows in 67 localities, mostly in the Polish part of the Western Tatra Mts and Belianske Tatra Mts (compare GóRsKI \& VÁŇA 2014). SZWEYKOWSKI (2006) estimated the plant's maximum in the Tatra Mts to be $1450 \mathrm{~m}$ a.s.l., probably based upon a locality in the Belianske Tatra Mts he discovered in 1956 (SZWEYKOWSKI 1960). In the following years, C. calcarea has been noted in the alpine belt of the Tatra Mts at an altitude of $1700 \mathrm{~m}$ a.s.l. (leg. J. Šmarda, 1961, leg. P. Górski, 2011), 1760 $\mathrm{m}$ a.s.l. (leg. P. Górski, 2011), and $2000 \mathrm{~m}$ a.s.l. (leg. J. Váňa, 1966; compare ŠMARDA 1961b, DudA \& VÁÑa 1975, GóRSKI \& VÁŇA 2014).

This work presents four new localities of Cololejeunea calcarea in the Tatra Mts. The first one was found in the Slovakian part of the High Tatra Mts, where only five localities have been recorded previously (SZYSZYŁOWICZ 1885, ŠMARDA 1961b, GóRSKI \& VÁŇA 2014); another two localities were found in the Slovakian Western Tatra Mts, where seven localities have been recorded previously (DUDA \& VÁŇA 1975, GÓRSKI \& VÁŇA 2014). The fourth locality was found in the Polish Western Tatra Mts (Czerwone Wierchy ridge), at an altitude of $1905 \mathrm{~m}$ a.s.l., which makes it the second highest locality in the Tatra Mts. The current altitude maximum of C. calcarea is $2000 \mathrm{~m}$ a.s.l. (Mount Plačlivý Roháč, Slovakian part of the Western Tatra Mts; DudA \& VÁŇA 1975).

\section{Dicranum viride (Sull. \& Lesq.) Lindb.}

Author: G. VončinA

ATMOS Ge-33: S Poland, Beskid Sądecki Range, Radziejowa ridge, Małopolska Province, Nowy Targ County, Ochotnica Dolna commune, village of Tylmanowa, Kłodne in Popradzki Landscape Park and 'Kłodne nad Dunajcem' nature reserve, $49.47514^{\circ} \mathrm{N}$, $20.43642^{\circ} \mathrm{E}$, alt. $417 \mathrm{~m}$ a.s.l., on the sandstone on the bank of the Dunajec River, det. G. Vončina, 17.05.2015.

Dicranum viride is a protected species under international law of the Bern Convention and the Habitat Directive; in Poland, it is a strictly protected taxon (Stebel 2012, Order... 2014). This species was treated as threatened in Europe (category V; SCHUMACKER 
\& Martiny 1995); in Poland and in the Polish Carpathians, it is a rare species (category R; ŻARNOwIEC et al. 2004). In Poland, D. viride was reported at a few scattered stations; the number of data has increased in recent years (Stebel et al. 2015). The species was noted in the northern part of Poland in the lowlands but most frequently in the Carpathians (STEBEL et al. 2015). It grows on the bark of deciduous trees, on decaying wood and on shadowed sandstones at altitudes from 300 to $1000 \mathrm{~m}$ a.s.l. (Lisowski 1956, STEBEL 2006, Armata 2008, Stebel et al. 2008, Żarnowiec \& SteBel 2014). Dicranum viride was reported from the Beskid Sądecki Range from the village of Żegiestów by ReHMAN (1869) and then by Limpricht (1890) initially. More recently, an occurrence of $D$. viride in the village of Żegiestów, in the Jaworzyna Krynicka ridge, was confirmed by Stebel et al. (2011). The described station is the first record in the Radziejowa ridge (Beskid Sądecki Range).

\section{Didymodon spadiceus (Mitt.) Limpr.}

Author: M. SMOCZYK

ATMOS Fb-25: SW Poland, Central Sudety Mountains (Sudety Środkowe), Góry Stołowe Mountains, Piekielna Dolina gorge between the towns of Szczytna and Polanica-Zdrój, Bystrzyca Dusznicka riverbank, $0.1 \mathrm{~km}$ west of the railway bridge, $50.3972^{\circ} \mathrm{N}$, $16.4915^{\circ} \mathrm{E}$, alt. $400 \mathrm{~m}$ a.s.l., on a sandstone boulder covered by a thin layer of alluvial loam, associated species: Chiloscyphus polyanthos, Codriophorus acicularis, Cratoneuron filicinum, Fissidens pusillus, Hygroamblystegium fluviatile, Lejeunea cavifolia, Lunularia cruciata (SMOCZYK \& WierzCHOLSKA 2014), and Thamnobryum alopecurum, leg., det. M. Smoczyk, 6.06.2014, conf. V. Plášek, c. spor. (POZG).

Didymodon spadiceus is a moss associated with baserich rock or humus substrates near water bodies and other places with high air humidity, especially in the mountains (KuČERA 2000, JIMÉNEZ et al. 2005). The species is rare in the Sudety Mts, and, thus far, D. spadiceus has not been reported from the Góry Stołowe Mts (SzMajda 1979).

8. Fissidens dubius P. Beauv. var. mucronatus Breidl. ex Limpr.) Karttunen, Hedenäs \& Söderström

\section{Author: G. VončInA}

ATMOS Ge-33: S Poland, Beskid Sądecki Range, Małopolska Province, Nowy Targ County, Ochotnica Dolna commune, village of Tylmanowa, Kłodne in Popradzki Landscape Park and Nature Reserve Kłodne nad Dunajcem, on the sandstone in the thermophilous beech forest, $49.47406^{\circ} \mathrm{N}, 20.43719^{\circ} \mathrm{E}$, alt. $418 \mathrm{~m}$ a.s.1., leg., det. G. Vončina, 17.05.2015, conf. A. Stebel (SOSN).

Fissidens dubius var. mucronatus is a rare taxon that was observed only in a few localities in West Pomerania, in the uplands belt, in the Polesia region and Carpathians in Poland (BRYLSKA 1991). This taxon was noted in the Kashubia region (HAJEK 2005), Świętokrzyskie Mountains (Stebel et al. 2013), Silesian foothills (SteBEL 2004a), Kotlina Żywiecka basin (STEBel et al. 2004, STEBEL 2006, 2008), Orawsko-Jordanowskie foothills (Stebel \& Vončina 2014), Beskid Mały Range (Stebel 2010), Beskid Makowski Range (Stebel 2006), Beskid Wysoki Range (Stebel et al. 2004, Stebel 2006), Beskid Wyspowy Range (Stebel 2006), Gorce Mts (Stebel 2004b, 2006), and Pieniny Range (Stebel et al. 2010) during the most recent decade. The moss grows on the calcareous soil in thermophilous grasslands, on wayside slopes, and in the undergrowth of deciduous forests (BRYLSKA 1991, SteBEL 2006). The lowermost locality in the Polish Carpathians is at 335 $\mathrm{m}$ a.s.l. and the highest at $800 \mathrm{~m}$ a.s.l. (Stebel 2006). The taxon was given from the Beskid Sądecki Range on Magura Hill (nearby town of Piwniczna) by BRYLSKA (1991) after verification of Mamczarz's collection.

\section{Fossombronia wondraczekii (Corda) Lindb.}

Author: M. SMOczYK

ATMOS Fb-26: SW Poland, Central Sudety Mts, Kłodzko Basin (Kotlina Kłodzka), Kłodzko commune, $2.4 \mathrm{~km}$ south-west of church in the village of Krosnowice, in the valley of the Duna Górna stream, $50.3815^{\circ} \mathrm{N}, 16.6180^{\circ} \mathrm{E}$, alt. $310 \mathrm{~m}$ a.s.l., damp clayey soil in a stubble field, in extensive patches of a Pottietum truncatae association, growing with Tortula truncata, Bryum rubens, Ephemerum serratum var. angustifolium, Anthoceros agrestis, and Riccia glauca, leg., det. M. Smoczyk, 20.09.2013, c. spor. (POZG); ATMOS Fb-36: SW Poland, Eastern Sudety Mts (Sudety Wschodnie), Śnieżnik Massif (Masyw Snieżnika), Krowiarki, near the village of Piotrowice Górne, $0.6 \mathrm{~km}$ north-west of Mount Kamiennik, $50.3302^{\circ} \mathrm{N}, 16.7223^{\circ} \mathrm{E}$, alt. 525 $\mathrm{m}$ a.s.l., clayey soil in the field margin, growing with Bryum rubens, Anthoceros agrestis, and Riccia glauca, leg., det. M. Smoczyk, 1.07.2014, c. spor. (POZG).

Fossombronia wondraczekii is a rare plant in Poland, endangered with extinction (category E; KLAMA 2006). In the Sudety Mts, it occurs in arable lands and stubbles, at lower altitudes only. In Kłodzko County, the species was given previously from the Stołowe Mountains (Milde 1864, SzWEYKowsKi 1953), the Orlickie foothills (KoŁa \& TurZańsKa 1993), the Bystrzyckie Mountains (KoŁA 1967), and the Bialskie Mountains (KoŁA 1972).

\section{Fuscocephaloziopsis macrostachya (Kaal.) Váňa} et L. Söderstr. (= Cephalozia macrostachya Kaal.)

Author: P. GóRSKI

ATMOS Ab-98: NW Poland, West Pomerania, Sławieńska Plain, Sławno County, Sławno Forest Inspectorate, 'Janiewickie Bagno' nature reserve, 
$54.25991^{\circ} \mathrm{N}, 16.71530^{\circ} \mathrm{E}, 54.25912^{\circ} \mathrm{N}, 16.71494^{\circ} \mathrm{E}$, $54.25982^{\circ} \mathrm{N}, 16.71467^{\circ} \mathrm{E}, 54.26016^{\circ} \mathrm{N}, 16.71634^{\circ} \mathrm{E}$, $54.25991^{\circ} \mathrm{N}, 16.72499^{\circ} \mathrm{E}, 54.2596^{\circ} \mathrm{N}, 16.71854^{\circ} \mathrm{E}$, in open part of peat bog, leg., det. P. Górski, 28.06.2016 (POZNB).

Fuscocephaloziopsis macrostachya has not been previously reported from the 'Janiewickie Bagno' nature reserve (see description of Cephaloziella elachista in this column). This species occurs very often in the open part of the peat bog. The distribution centre of F. macrostachya in Poland is situated in the northern part of the country (SzweYKowski 2006). From West Pomerania, the species has been recently reported by GÓRSKI (2013), GóRSKI \& GĄBKA (2015b), and GóRSKI \& KAPUSTYŃSKI (2015b). SZWEYKOWSKI (2006) has stated that this species is actually more frequent than it would appear from the published data. It seems that it may have much more localities in West Pomerania.

\section{Hypnum cupressiforme Hedw. var. subjulaceum Molendo}

Author: G. VončinA

ATMOS Ge-33: S Poland, Beskid Sądecki Range, Małopolska Province, Nowy Targ County, Ochotnica Dolna commune, village of Tylmanowa, Kłodne in Popradzki Landscape Park and Nature Reserve Kłodne nad Dunajcem, on the sandstone on the bank of the Dunajec River, $49.47514^{\circ} \mathrm{N}, 20.43642^{\circ} \mathrm{E}$, alt. $417 \mathrm{~m}$ a.s.l., leg., det. G. Vončina, 17.05.2015, conf. A. Stebel (SOSN); on the sandstone in the thermophilous beech forest, $49.47406^{\circ} \mathrm{N}, 20.43719^{\circ} \mathrm{E}$, alt. $418 \mathrm{~m}$ a.s.l., leg., det. G. Vončina, 17.05.2015, conf. A. Stebel (SOSN).

Hypnum cupressiforme var. subjulaceum is a very rare taxon that has been noted only in a few places in the Polish Carpathians (WiśniewsKa 1957, SzAFran 1961). It grows on the sunny or shady outcrops or boulders that are built of limestone, andesite, and sandstone at an altitude of $\sim 300$ to $1850 \mathrm{~m}$ a.s.l. (WIŚNIEWSKA 1957, Lisowski 1959, JęDRZEjKo 1970, Stebel 2006, ŻARnOwiec \& STEBel 2014). The moss was observed in the Rożnowskie foothills (SzAFran 1954), Beskid Mały Range (Stebel 2006, 2010), Beskid Wysoki Range (Stebel 2004c, Stebel et al. 2004, Żarnowiec \& Szwed 2004, Stebel 2006), Beskid Sądecki Range (on the andesites of Bryjarka Hill; JęDRZEjKo 1970), Gorce Mts (Lisowski \& Kornaś 1966, J̨̨DRZejKo 1970, Stebel 2006), Tatra Mts (Lisowski 1958, 1959, SzaFRAN 1961, CYKowsKa 2008), Pieniny Range (SZAFran 1952, 1954, WiśNIEWSKA 1957, LISOWSKi 1958, ОснYRA \& Stebel 2008, Stebel et al. 2010), and Bieszczady Mountains (Lisowski 1956, Stebel \& ŻarnowieC 2010). The described locality is the first observation of this taxon on sandstone of Carpathian flysch in the Beskid Sądecki Range (mats of moss without sporophytes).

\section{Lophozia ascendens (Warnst.) R.M. Schust.}

\section{Author: P. GóRsKI}

Slovakia Belianske Tatra Mts: MGRS 34UDV4256, Západné Belianske Tatry, Tristarská dolina valley, middle part of Złoty Żleb gully, $49.25995^{\circ} \mathrm{N}$, $20.20928^{\circ} \mathrm{E}$, alt. $1215 \mathrm{~m}$ a.s.l., decaying $\log$, leg., det. P. Górski, 7.11.2015 (POZNB 2070); High TATRA MTs: MGRS 34UDV2647, Skupina Kriváňa, lower part of Nefcerka valley, $49.17557^{\circ} \mathrm{N}, 19.99087^{\circ} \mathrm{E}$, alt. 1395 $\mathrm{m}$ a.s.l., decaying log in spruce forest, leg., det. P. Górski, 16.09.2015 (POZNB 2068); MGRS 34UDV3753, Skupina Širokej, lower part of the Svištovská dolina valley, decaying $\log$ in spruce forest, $49.23156^{\circ} \mathrm{N}$, $20.13879^{\circ} \mathrm{E}$, alt. $1245 \mathrm{~m}$ a.s.l., leg., det. P. Górski, 6.11.2015 (POZNB 2069); Western Tatra Mts: MGRS 34UDV0757, Skupina Osobitej-Bobrovca, Suchá dolina valley, lower part of Široký žlab gully, $49.26585^{\circ} \mathrm{N}, 19.72963^{\circ} \mathrm{E}, 49.26642^{\circ} \mathrm{N}, 19.73153^{\circ} \mathrm{E}$, alt. $1135 \mathrm{~m}$ a.s.l., $1215 \mathrm{~m}$ a.s.l., decaying log, leg., det. P. Górski, 24.09.2015 (POZNB 2062, 2063); MGRS 34UDV0757, Skupina Osobitej-Bobrovca, middle part of Suchá dolina valley, $49.26508^{\circ} \mathrm{N}, 19.73822^{\circ} \mathrm{E}$, alt. $1045 \mathrm{~m}$ a.s.l., decaying log near stream, leg., det. P. Górski, 24.09.2015 (POZNB 2066).

Lophozia ascendens is an epixylic liverwort that is relatively frequent in the Tatra Mts. In the entire area of the Tatra Mts, 43 localities of $L$. ascendens have been recorded within an altitude range of 800 to $1800 \mathrm{~m}$ a.s.l. (GóRSKI \& VÁŇA 2014). In the Polish part of the Tatra Mts, this liverwort is considered rare (Szweykowski \& Klama 2010). This is based upon the lack of data on the occurrence of the plant in the Polish High Tatra Mts and the presence of only seven localities in the Polish Western Tatra Mts. However, this is the result of an insufficient state of knowledge due to limited studies, and, in the Polish part of the massif, the species is likely more common. Aside from the Tatra Mts, L. ascendens is very rare in lowlands, and it may be an indicator species for well-preserved forests with a long ecological continuity (primeval forests).

\section{Mesoptychia heterocolpos (Thed. ex Hartm.) L.} Söderstr. et Váňa [ = Lophozia heterocolpos (Thed. ex Hartm.) M. Howe]

\section{Author: P. GóRSKI}

Slovakia, High Tatra Mts: MGRS 34UDV3652, Skupina Širokej, lower part of the Široká dolina valley, $49.22435^{\circ} \mathrm{N}, 20.13149^{\circ} \mathrm{E}, 49.22435^{\circ} \mathrm{N}, 20.13149^{\circ} \mathrm{E}$, alt. $1535 \mathrm{~m}$ a.s.l., calcareous outcrops of dwarf mountain pine, leg., det. P. Górski, 9.11.2015 (POZNB 1995, 2048); Skupina Širokej, upper part of the Široká dolina valley, $49.22059^{\circ} \mathrm{N}, 20.13159^{\circ} \mathrm{E}$, alt. $1625 \mathrm{~m}$ a.s.l., calcareous outcrops, leg., det. P. Górski, 9.11.2015 (POZNB 2049); MGRS 34UDV3653, Skupina Širokej, lower part of the Široká dolina valley, $49.22805^{\circ} \mathrm{N}$, 
$20.13076^{\circ} \mathrm{E}$, alt. $1390 \mathrm{~m}$ a.s.l., calcareous boulder, leg., det. P. Górski, 9.11.2015 (POZNB 2045), Skupina Širokej, lower part of the Svištovská dolina valley, $49.22746^{\circ} \mathrm{N}, 20.13101^{\circ} \mathrm{E}$, alt. $1415 \mathrm{~m}$ a.s.l., leg., det. P. Górski, rock crevices, on humus, 9.11.2015 (POZNB 2046, 2047); MGRS 34UDV3752, Skupina Širokej, upper part of the Svištovská dolina valley, $49.22237^{\circ} \mathrm{N}, 20.14153^{\circ} \mathrm{E}, 49.22257^{\circ} \mathrm{N}, 20.14188^{\circ} \mathrm{E}$, $49.22554^{\circ} \mathrm{N}, 20.14003^{\circ} \mathrm{E}$, alt. $1505 \mathrm{~m}$ a.s.l., $1620 \mathrm{~m}$ a.s.l., and $1630 \mathrm{~m}$ a.s.l., rock crevices, on humus, leg., det. P. Górski, 8.11.2015 (POZNB 1988, 1997); MGRS 34UDV3753, Skupina Širokej, lower part of the Svištovská dolina valley, $49.22831^{\circ} \mathrm{N}, 20.13996^{\circ} \mathrm{E}$, alt. $1345 \mathrm{~m}$ a.s.1., rock crevices, on humus, leg., det. P. Górski, 6.11.2015 (POZNB 2043).

Poland, Western Tatra Mts: MGRS 34UDV2054, ATMOS Gd-59, Masyw Czerwonych Wierchów, Dolina Mułowa valley, bottom plateau of the kettle, $49.23403^{\circ} \mathrm{N}, 19.90495^{\circ} \mathrm{E}$, alt. $1820 \mathrm{~m}$ a.s.l., leg., det. P. Górski, 22.09.2015 (POZNB 2040).

Mesoptychia heterocolpos is an arctic-alpine species growing on the humus of calcareous rocks that is relatively rare in the Tatra Mts. In the entire area of the Tatra Mts, 28 localities of M. heterocolpos have been recorded within an altitude range of 1140 to 2148 m a.s.l. (GóRSKI \& VÁŇA 2014). Most of the localities presented above come from the Slovakian High Tatra Mts. In this part of the Tatra Mts, only five records of M. heterocolpos are known (SZWEYKOWSKI 1960, DUDA \& VÁŇA 1989, GóRSKI \& VÁŇA 2014). The data presented in this work originate from valleys with northern exposure, from the vicinity of Mount Široká, where $M$. heterocolpos is a frequent species.

\section{Nowellia curvifolia (Dicks.) Mitt.}

\section{Author: M. SMOcZYK}

ATMOS Da-04: W Poland, Lubuskie Lakeland, Torzym Plain, $4.2 \mathrm{~km}$ south-east of the city of Rzepin, southern shore of Jezioro Rzepsko Lake, forest section $422 \mathrm{f}$ of the Rzepin Forest Inspectorate, $52.3186^{\circ} \mathrm{N}, 14.8865^{\circ} \mathrm{E}$, decaying pine log on the lakeshore, growing with Lophocolea heterophylla, Aulacomnium androgynum, Brachythecium rutabulum, and Hypnum cupressiforme, leg., det. M. Smoczyk, 4.04.2015, c. per. (POZG).

Nowellia curvifolia is a lignicolous liverwort associated with coniferous wood. It occurs mainly in north-eastern Poland (Szweykowski 1969, 2006). According to SzWEYKOWSKI (2006), the species is rare or absent in western Poland. However, some new records have been published recently from the north-western part of the country (GóRSKI 2010, 2013, GóRSKI \& GĄBKA 2015c, GóRsKi \& KapustyŃSKi 2015c, Wilhelm et al. 2015), which reveal this species to be no longer rare in the West Pomerania region. Thus far, N. curvifolia has not been reported from the Pojezierze Lubuskie Lakeland.
14. Nowellia curvifolia (Dicks.) Mitt.

Author: M. WilheLM

ATMOS Ba-27: NW Poland, West Pomerania, Gryficka Plain, West Pomerania Province, Gryfice County, Gryfice commune, Modlimowo-Grądy peat bog near Przybiernówko (the so-called 'Wielkie Smogorze'), $53.97664^{\circ} \mathrm{N}, 15.14169^{\circ} \mathrm{E}$, forest section 246 of the Gryfice Forest Inspectorate, on a decaying pine log in a Vaccinio uliginosi-Pinetum plant association, leg., det. M. Wilhelm, 23.09.2012 (SZUB).

\section{Rhytidiadelphus loreus (Hedw.) Warnst.}

\section{Author: R. ŠolTÉs}

Slovakia, TATRA Mts: The goal of this contribution is to explain why Rhytidiadelphus loreus on the southern slopes of the Tatra Mts in forest ecosystems is missing.

In Slovakia, Rhytidiadelphus loreus is abundant and is widespread in mountain areas on soil in humid habitats, on boulders, on fallen logs, or on marshy ground (Fajmonová 1979, PeCiar 1979, Majzlanová 1982, Herben \& SoldÁn 1987). Quite different is the situation in the Tatra Mts, where on the southern slopes the moss is virtually lacking. It seems that $R$. loreus is confined to the climax forest stage. Unfortunately, the forests developed on the leeward side of the Tatra Mts have been irregularly affected by the recurrent northern down-slope winds. North-facing valleys are unaffected by recurrent northern wind, because air masses from the north are due to the high air pressure forced to ridges, where the air becomes cool and heavier and falls down the southern slopes, gaining the kinetic energy. The last event happened in 2004, when 12000 ha of forest was blown down. Since 1915, this was the seventh large-scale event in this forest, affecting more or less the same forest sections. The forest thus seldom reaches its climax stage due to these natural disturbances, which is why in this area the moss $R$. loreus is lacking. On the southern slopes of the Tatras, the moss occurs rarely but above the timberline in the dwarf pine zone (i.e., in areas unaffected by windbreaks) (ŠMARDA 1948, 1952, 1961a). Locations in the Belianske Tatras are of course unaffected by windbreaks (ŠMARDA 1961a, BLACKBURN et al. 1997). On the unaffected north-facing slopes, the moss occurs abundantly, forming large carpets (ŠMARDA 1958 - Kačacia dolina valley, Bielovodská dolina valley; PeCIAR 1978 - Bielovodská dolina valley). Many specimens of $R$. loreus collected in the Bielovodská dolina valley or Javorová dolina valley at an altitude of 1014 to $1310 \mathrm{~m}$ a.s.l. are deposited in the Herbarium of the Tatra National Park (TANAP) in Tatranská Lomnica. Records of CHAŁUBIŃSKI (1886) in the Mengusovská dolina valley and of Šmarda (1948) close to the Štrbské pleso lake are still unconfirmed. Our belief that $R$. loreus is an 
indicator of natural forests is also supported by ODOR \& DorT (2002); R. loreus indicates natural forests in Slovenia.

\section{Saccobasis polita (Nees) H. Buch [= Tritomaria polita (Nees) Jörg.]}

Author: H. KLAMA

ATMOS Gd-59: S Poland, Western Tatra Mts, Dolina Litworowa valley, rocks at the base of the western-northern-western slope of Mount Małołączniak, alt. $1850 \mathrm{~m}$ a.s.l., on humus covering calcareous rocks, leg., det. H. Klama, 20.09.1989, ster. (herb. H. Klama).

In Poland, this epipetric liverwort occurs in alpine and subalpine zones in the Tatra Mts only (SzWEYKOWsKI \& Koźlicka 1980, SzweYKowski 2006). In the Polish part of the Tatra Mts, Saccobasis polita grows at 15 stations (i.e., in the Western Tatra Mts at two stations and in the High Tatra Mts at 13; GóRSKI \& VÁŇA 2014).

\section{Trichocolea tomentella (Ehrh.) Dumort.}

Author: H. KLAMA

ATMOS Gd-34: S Poland, Beskid Żywiecko-Orawski Mountains, Wielka Racza group (Grupa Wielkiej Raczy), Silesian Province, Żywiec County, village of Soblówka, valley of the Urwisko stream, orographic left side of the valley, $49.42985^{\circ} \mathrm{N}, 19.14805^{\circ} \mathrm{E}$, alt. 673 m a.s.l., on wet soil in swamp with Caltha palustris in spruce forest, leg., det. H. Klama, 1.07.2015, ster. (herb. H. Klama).

Trichocolea tomentella is very rare species in the Polish mountains (SzWEYKowsKi 2006). It grows in the lower forest belt in wet places, near streams, and in spring areas. In the Beskid Żywiecko-Orawski Mts, the plant is known thus far from one location (KLAMA 1996), and this is second station of the species in this territory. This liverwort also has been recorded at single stations in the Silesian foothills (WILCZEK \& ZARZYCKI 2013), Beskid Śląski Mountains (RejMENT-GrochowsKa 1950, MierZEŃSKA \& DreWNioK 2000, PlášeK \& Stebel 2002), Beskid Mały Mountains (Stebel \& Stebel 1998), Babia Góra Massif (Stebel 2002, Klama 2004), Gorce Mts (MierZeńsKa 1994), and Beskid Niski Mountains (CyKowsKa-MarzencKA 2014).

\section{REFERENCES}

Armata L. (2008): A contribution to the moss flora of the eastern part of the Polish Carpathians. In: A. Stebel, R. Ochyra (eds). Bryophytes of the Polish Carpathians. Sorus, Poznań: 169-178.

Blackburn J.M., Blockeel T.L., Buryová B., Нomm T., Martin P., Porley R.D., Šoltés R., Whitehous H.L.K. (1997): British Bryological Society excur- sion to Slovakia: Site Lists. Štúdie o Tatranskom národnom parku 2(35): 169-182.

BRYLSKA B. (1991): Fissidens cristatus var. mucronatus (Musci, Fissidentaceae), zapomniany takson we florze mchów Polski. Fragmenta Floristica et Geobotanica 35(1-2): 239-244.

ChAeUbiŃski T. (1886): Enumeratio Muscorum frondosum Tatrensium. Pamiętnik Fizyjograficzny 6: $1-207$.

Сүкошsка В. (2008): A contribution to the bryoflora of the subnival belt in the Polish Tatra Mountains. In: A. Stebel, R. Ochyra (eds). Bryophytes of the Polish Carpathians. Sorus, Poznań: 185-200.

CYKowsKa-Marzencka B. (2014): 24. Trichocolea tomentella (Ehrh.) Dumort. In: P. Górski, A. Stebel., A Rusińska (eds). New distributional data on bryophytes of Poland, 1. Steciana 18(2): 83.

DudA J., VÁŇA J. (1975): Die Verbreitung der Lebermoose in der Tschechoslowakei. XVIII. Časopis Slezského Muzea, Series A, Opava 24: 169-187.

DudA J., VÁŇA J. (1984): Rozšířrení játrovek v Československu. XXXIX. Časopis Slezského Muzea, Series A, Opava 33: 1-16.

DudA J., VÁŇA J. (1989): Rozšíření játrovek v Československu. LVI. Časopis Slezského Muzea, Series A, Opava 38: 209-224.

FAJMONOVÁ E. (1979): Waldgesellschaften des Verbandes Vaccinio-Piceion Br.-Bl. 1939 im Naturschutzgebiet und in der Schutzzone Slovenský raj. Acta Facultatis Rerum Naturalium Universitatis Comenianae, Seria Botanica 27: 53-75.

FudAli E., SzCZEPAŃSKI M., RusińsKa A., RosadZiŃsKI S., Wolski G. (2009): The current distribution in Poland of some European neophytic bryophytes with supposed invasive tendencies. Acta Societatis Botanicorum Poloniae 78(1): 73-80.

GóRSKI P. (2010): A contribution to the liverwort flora of the Drawsko lake district (Western Pomerania, Poland). Roczniki Akademii Rolniczej w Poznaniu 389, Botanika-Steciana 14: 19-26.

GóRSKI P. (2013): Wątrobowce (Marchantiophyta) Leśnego Kompleksu Promocyjnego „Lasy Środkowopomorskie" (Pomorze Zachodnie). PGL Lasy Państwowe Nadleśnictwo Karnieszewice, Wydawnictwo Uniwersytetu Przyrodniczego w Poznaniu, Sianów-Poznań.

GóRSKI P. (2014): 3. Campylopus introflexus (Hedw.) Brid. In: P. Górski, A. Stebel, A. Rusińska (eds). New distributional data on bryophytes of Poland, 1. Steciana 18(2): 78.

GóRsKI P. (2015): 3. Campylopus introflexus (Hedw.) Brid. In: P. Górski, A. Rusińska (eds). New distributional data on bryophytes of Poland, 2. Steciana 19(2): 57.

GóRsKI P. (2016): 1. Anastrophyllum michauxii (F. Weber) H. Buch. In: P. Górski, A. Rusińska (eds). New distributional data on bryophytes of Poland and Slovakia, 5. Steciana 20(1): 33-34. 
GóRski P., GĄBKa M. (2015a): 4. Cephaloziella elachista (J.B. Jack ex Gottsche et Rabenh.) Schiffn. In: P. Górski, A. Rusińska (eds). New distributional data on bryophytes of Poland, 2. Steciana 19(2): 57.

GÓRSKI P., GĄBKA M. (2015b): 8. Fuscocephaloziopsis macrostachya (Kaal.) Váňa et L. Söderstr. (= Cephalozia macrostachya Kaal.). In: P. Górski, A. Rusińska (eds). New distributional data on bryophytes of Poland, 2. Steciana 19(2): 58.

GóRsKi P., GĄBKA M. (2015c): 15. Nowellia curvifolia (Dicks.) Mitt. In: P. Górski, A. Rusińska (eds). New distributional data on bryophytes of Poland, 2. Steciana 19(2): 59-60.

GóRsKi P., KapustyŃsKi T. (2015a): 1. Campylopus introflexus (Hedw.) Brid. In: P. Górski, A. Rusińska (eds). New distributional data on bryophytes of Poland, 4. Steciana 19(4): 221.

GóRsKi P., KAPUSTYŃsKi T. (2015b). 7. Fuscocephaloziopsis macrostachya (Kaal.) Váňa et L. Söderstr. (= Cephalozia macrostachya Kaal.). In: P. Górski, A. Rusińska (eds). New distributional data on bryophytes of Poland, 4. Steciana 19(4): 223.

GóRSKi P., KAPUSTYŃSKi T. (2015c): 13. Nowellia curvifolia (Dicks.) Mitt. In: P. Górski, A. Rusińska (eds). New distributional data on bryophytes of Poland, 4. Steciana 19(4): 225.

Górski P., Kapustyński T., Smoczyk M. (2015): 3. Cephaloziella elachista (J.B. Jack ex Gottsche et Rabenh.) Schiffn. In: P. Górski, A. Rusińska (eds). New distributional data on bryophytes of Poland, 4. Steciana 19(4): 222.

GóRSKI P., VÁŇA J. (2014): A synopsis of liverworts occurring in the Tatra Mountains (Western Carpathians, Poland and Slovakia): checklist, distribution and new data. Preslia 86(4): 381-485.

HajeK B. (2005): Fissidens dubius P. Beauv. var. mucronatus (Breidl. ex Limpr.) Karttunen, Hedenäs \& Söderström - a new taxon in moss flora of Kaszubskie Lakeland (NW Poland). Acta Botanica Cassubica 5: 167-170.

Herben T., SoldÁn Z. (1987): Bryofloristic material from the central part of Muránska planina (Western Carpathians). Preslia 59: 65-85.

JęDRZEjKo K. (1970): Mszaki terenów andezytowych w okolicach Czorsztyna i Szczawnicy. Fragmenta Floristica et Geobotanica 16(4): 521-536.

Jiménez J.A., Ros R.M., CANo M.J., Guerra J. (2005): A revision of Didymodon section Fallaces (Musci, Pottiaceae) in Europe, North Africa, Macaronesia, and southwest and central Asia. Annals of the Missouri Botanical Garden 92: 225-247.

KARCZMARz K. (2000): Mszaki (Bryophyta). In: J. Razowski (ed.). Flora i fauna Pienin. Monografie Pienińskie 1: 67-74.

Klama H. (1996): Wątrobowce (Hepaticae) Beskidu Żywiecko-Orawskiego (Karpaty Zachodnie). Monographiae Botanicae 79: 1-144.
Klama H. (2004): Wątrobowce (Marchantiophyta) Babiogórskiego Parku Narodowego. In: B.W. Wołoszyn, A. Jaworski, J. Szwagrzyk (eds). Babiogórski Park Narodowy. Monografia Przyrodnicza. Komitet Ochrony Przyrody PAN, Babiogórski Park Narodowy, Kraków: 333-356.

Klama H. (2006): Red list of the liverworts and hornworts in Poland. Czerwona lista watrobowców i glewików w Polsce. In: Z. Mirek, K. Zarzycki, W. Wojewoda, Z. Szeląg (eds). Red list of plants and fungi in Poland. Czerwona lista roślin i grzybów Polski. W. Szafer Institute of Botany, Polish Academy of Sciences, Kraków: 21-33.

KoŁA W. (1967): Materiały do flory wątrobowców Gór Bystrzyckich. Acta Universitatis Wratislaviensis 62, Prace Botaniczne 8: 85-98.

KoєA W. (1972): Rozmieszczenie wątrobowców w Górach Bialskich. Prace Opolskiego Towarzystwa Przyjaciół Nauk, Wydział III Nauk Przyrodniczych, Państwowe Wydawnictwo Naukowe, Warszawa-Wrocław.

KoŁA W., TurzańsKa M. (1993): Zbiorowiska mszaków pól uprawnych Dolnego Śląska. I. Acta Universitatis Wratislaviensis 148, Prace Botaniczne 53: 3-12.

KuČERA J. (2000): Illustrierter Bestimmungsschlüssel zu den mitteleuropäischen Arten der Gattung Didymodon. Meylania 19: 1-49.

Limpricht K.G. (1890): Die Laubmoose Deutschlands, Oesterreichs und der Schweiz. In: Dr L. Rabrnhorst's Kryptogramen-Flora von Deutschlands, Oesterreichs und der Schweiz. 2 Aufl. 4(1) - Sphagnaceae, Andreaeaceae, Archidiaceae, Bryineae (Cleistocarpeae, Stegocarpae [Acrocarpae]). Eduard Kummer, Leipzig: viii +836.

Lisowski S. (1956): Mchy Bieszczadów Zachodnich. Prace Komisji Biologicznej Poznańskiego Towarzystwa Przyjaciół Nauk 17(3): 1-95.

Lisowski S. (1958): Bryotheca Polonica. Fasc. 40. No. 1026-1050. Musci Montium Pieniny. Academia Scientiarum Poloniae, Posnaniae.

Lisowski S. (1959): Materiały do bryoflory Tatr. Prace Komisji Biologicznej Poznańskiego Towarzystwa Przyjaciół Nauk 21(2): 1-129.

LisowsKi S., Kornaś J. (1966): Mchy Gorców. Fragmenta Floristica et Geobotanica 12(1): 41-114.

Majzlánová E. (1982): Phytozönotische und Produktions - Charakteristik der Assoziation Vaccinio myrtilli-Piceetum (Szaf., Pawl., Kulcz. 23) Šoltés 76. Acta Facultatis Rerum Naturalium Universitatis Comenianae, Seria Botanica 29: 103-112.

MierzeńsKa M. (1994): Wątrobowce Gorców. Fragmenta Floristica et Geobotanica Polonica, Series Polonica 1: 235-346.

Mierzeńska M., Drewniok B. (2000): Wątrobowce (Hepaticae) Doliny Białej Wisełki (Beskid Śląski, Karpaty Zachodnie). Fragmenta Floristica et Geobotanica Polonica 7: 305-332. 
MiLDE J. (1864): Zur Flora von Cudowa. Jahresbericht der Schlesischen Gesellschaft für vaterländische Cultur 42: 120-125.

MiLde J. (1869): Bryologia Silesiaca. Laubmoos-Flora von Nord- und Mittel-Deutschland unter besonderer Berücksichtigung Schlesiens und mit Hinzunahme der Floren von Jütland, Holland, der Rheinpfalz, von Baden, Franken, Böhmen, Mähren und der Umgegend von München. Arthur Felix, Leipzig: ix +410.

Ochyra R., Stebel A. (2008): Mosses of the Małe Pieniny Range (Polish Western Carpathians). In: A. Stebel, R. Ochyra (eds). Bryophytes of the Polish Carpathians. Sorus, Poznań: 75-141.

Ódor P., VAN Dort K. (2002): Beech dead wood inhabiting bryophyte vegetation in two Slovenian forest reserves. Zbornik gozdarstva in lesarstva 69: 155-169.

ORDER of the Ministry of Environment on 9 October 2014 (2014): Official Gazette Announcing Current Legislation item 1409.

Peciar V. (1978): Studia bryofloristica Slovaciae 9. Acta Facultatis Rerum Naturalium Universitatis Comenianae, Seria Botanica 26: 43-52.

Peciar V. (1979): Studia bryofloristica Slovaciae 11. Acta Facultatis Rerum Naturalium Universitatis Comenianae, Seria Botanica 27: 151-161.

Plášek V., Stebel A. (2002): Bryophytes of the Čantoryjský hrrbet range (Czantoria range) and its foothills (Western Carpathians - Czech Republic, Poland). Časopis Slezského Zemského Muzea Opava (A) 51: 1-87.

ReHmAn A. (1865): Versuch einer Aufzählung der Laubmoose von Westgalizien. Verhandlungen der Zoologisch-Botanischen Gesellschaft in Wien 15: 461-484.

Rehman A. (1869): Zapisek botaniczny znad brzegów Popradu. Sprawozdania Komisyi Fizyograficznej Towarzystwa Naukowego Krakowskiego 3: 56-66.

RejMENT-GrochowsKA I. (1950): Czynniki ekologiczne i rozmieszczenie geograficzne wątrobowców (Hepaticae) Beskidu Śląskiego. Prace Biologiczne Śląskie 2: 3-71.

Schumacker R., Martiny P. (1995): Red Data Book of European bryophytes. Part 2. Threatened bryophytes in Europe including Macaronesia. The European Committee for Conservation of Bryophytes, Trondheim.

ŠMARDA J. (1948): Mechy Slovenska. Časopis Moravského zemského muzea 32: 1-75.

Šmarda J. (1952): První doplněk k Mechům Slovenska. Časopis Moravského zemského muzea 37: 26-31.

ŠMARDA J. (1958): Doplněk k mechům Slovenska. 4. Biologické práce 4/7: 7-35.

ŠMARDA J. (1961a): Doplněk k mechům Slovenska. 5. Biologické práce 7/1: 47-75.
ŠMARDA J. (1961b): Příspěvky k rozšíření jatrovek v Československu 6. Biologické práce 7/1: 5-45.

SmoczyK M., WierzcholsKa S. (2014): Księżyczka krzyżowa Lunularia cruciata (L.) Lindb. (Lunulariaceae, Marchantiophyta) na Dolnym Śląsku. Przyroda Sudetów 17: 3-10.

Stebel A. (2002): Hepaticae Macroregioni Meridionali Poloniae Exsiccati. Liverworts of southern Poland. Fasciculus 16 (No. 226-275). Medical University of Silesia in Katowice, Katowice.

Stebel A. (2004a): A contribution to the bryoflora of the Western part of the Carpathian Foothills. In: A. Stebel, R. Ochyra (eds). Bryological studies in the Western Carpathians. Sorus, Poznań: $135-145$.

Stebel A. (2004b): A contribution to the moss flora of the Gorce (Western Carpathians). In: A. Stebel, R. Ochyra (eds). Bryological studies in the Western Carpathians. Sorus, Poznań: 127-134.

Stebel A. (2004c): Mchy Babiej Góry. In: B.W. Wołoszyn, A. Jaworski, J. Szwagrzyk (eds). Babiogórski Park Narodowy. Monografia przyrodnicza. Komitet Ochrony Przyrody PAN, Babiogórski Park Narodowy, Kraków: 357-378.

Stebel A. (2006): The mosses of the Beskidy Zachodnie as a paradigm of biological and environmental changes in the flora of the Polish Western Carpathians. Medical University of Silesia in Katowice, Sorus, Katowice, Poznań.

Stebel A. (2008): Mosses of the Kotlina Żywiecka Basin (Western Carpathians). In: A. Stebel, R. Ochyra (eds). Bryophytes of the Polish Carpathians. Sorus, Poznań: 11-74.

Stebel A. (2010): Mosses of the Beskid Mały Range (Western Carpathians). Materiały Opracowania, 11. Centrum Dziedzictwa Przyrody Górnego Śląska, Katowice.

Stebel A. (2012): Widłoząb zielony Dicranum viride (Sull. \& Lesq.) Lindb. In: J. Perzanowska (ed.). Monitoring gatunków roślin. Przewodnik metodyczny. Część 2. GIOŚ, Warszawa: 296-306.

Stebel A., Cykowska B., Żarnowiec J. (2011): Current distribution of the European threatened moss Dicranum viride (Bryophyta, Dicranaceae). In: A. Stebel, R. Ochyra (eds). Chorological studies on Polish Bryophytes. Sorus, Poznań: 99-110.

Stebel A., Krause R., Stachnowicz W., Nejfeld P., WilCZEK Z., GóRSKI P. (2004): A contribution to the bryoflora of the Western Beskidy. In: A. Stebel, R. Ochyra (eds). Bryological studies in the Western Carpathians. Sorus, Poznań: 153-160.

Stebel A., Ochyra R., Stuchlik L., Parusel J.B. (2004): Mosses of the Polica Range (Polish Western Carpathians). Sorus, Poznań.

Stebel A., Ochyra R., Vončina G. (2010): Mosses of the Pieniny Range (Polish Western Carpathians). Sorus, Poznań. 
Stebel A., Rosadziński S., Górski P., Fojcik B., Rusińska A., Vončina G., Szczepański M., Wilhelm M., Fudali E., Paciorek T., Staniaszek-Kik M., Zubel R., Piwowarski B., Wolski G.J., Salachna A., SmolińSKA D., PIERŚcińsKA A. (2013): Contribution to the bryoflora of the Świętokrzyski National Park (Central Poland). Roczniki Akademii Rolniczej w Poznaniu 392, Botanika-Steciana 17: 77-84.

Stebel A., Rosadziński S., Wierzcholska S., Zubel R., Paciorek T. (2015): New distributional data for the moss Dicranum viride in Poland. Herzogia 28(1): 38-43.

Stebel A., Stebel A.M. (1998): Materiały do brioflory Beskidu Małego i północnej części Kotliny Żywieckiej (Karpaty Zachodnie). Fragmenta Floristica et Geobotanica, Series Polonica 5: 217-36.

Stebel A., Vončina G. (2014): Bryophyte diversity in the flora of the Orawsko-Jordanowskie Foothills (Polish Western Carpathians). Muzeum Tatrzańskie, Zakopane.

Stebel A., ŻARnowiec J. (2010): Materiały do flory mchów Bieszczadów Zachodnich (Karpaty Wschodnie). Roczniki Bieszczadzkie 18: 134-156.

Stebel A., Żarnowiec J., Cykowska B., Szczepański M. (2008): Additional localities of the European threatened moss Dicranum viride (Bryophyta, Dicranaceae) from Poland. In: A. Stebel, R. Ochyra (eds). Bryophytes of the Polish Carpathians. Sorus, Poznań: 271-274.

Szafran B. (1952): Mchy Pienin. Ochrona Przyrody 20: 89-117.

SzAFrAN B. (1954): Zapiski bryologiczne z Karpat Zachodnich (Beskidy, Tatry, Pieniny). Fragmenta Floristica et Geobotanica 2(1): 143-167.

Szafran B. (1961): Mchy (Musci). 2. Państwowe Wydawnictwo Naukowe, Warszawa.

Szmajda P. (1979): Bryoflora Gór Stołowych i jej charakterystyka geobotaniczna. Prace Komisji Biologicznej Poznańskiego Towarzystwa Przyjaciół Nauk 52: 1-79.

SzweYkowski J. (1953): Mszaki Gór Stołowych. Cz. 1. Wątrobowce (Hepaticae). Prace Komisji Biologicznej Poznańskiego Towarzystwa Przyjaciół Nauk 14(5): 1-134.

SzWEYKOWSKI J. (1960): Materiały do flory wątrobowców Tatr. Prace Komisji Biologicznej Poznańskiego Towarzystwa Przyjaciół Nauk 21 (3): 3-92.

SzWEYKowski J. (1969): H. 213. Nowellia curvifolia (Dicks.) Mitten. In: J. Szweykowski, T. Wojterski (eds). Atlas of geographical distribution of spore-plants in Poland. Vol. 6. Ser. 4. Liverworts (Hepaticae). Polska Akademia Nauk, Poznańskie Towarzystwo Przyjaciół Nauk, Poznań.

SzWEYKOWSKI J. (2006): An annotated checklist of Polish liverworts and hornworts. - Krytyczna lista wątrobowców i glewików Polski. Biodiversity of Poland. Vol. 4. W. Szafer Institute of Botany, Polish Academy of Sciences, Kraków.
SzWEyKOwsKi J., Klama H. (2010): Liverworts of the Tatra National Park - a checklist. In: Z. Mirek, M. Ronikier (eds). Biodiversity of the Tatra National Park. Vol. 3. W. Szafer Institute of Botany, Polish Academy of Sciences, Kraków.

SzweYKowsKi J., KoźlickA M. (1969): Materiały do flory wątrobowców Pomorza. Badania Fizjograficzne nad Polską Zachodnią 23: 125-149.

SzWEYKOWSKI J., KoźLICKA M. (1980): H. 107. Saccobasis polita (Nees) Buch. In: J. Szweykowski, T. Wojterski (eds). Atlas of geographical distribution of spore-plants in Poland. Vol. 10. Ser. 4. Liverworts (Hepaticae). Państwowe Wydawnictwo Naukowe, Warszawa-Poznań: 25.

Szyszyłowicz I. (1885): O rozmieszczeniu wątrobowców w Tatrach. Sprawozdanie Komisyi Fizyjograficznej 19: 4-125.

Vončina G., Stebel A. (2016): Materiały do flory mchów Pienińskiego Pasa Skałkowego (Karpaty Zachodnie). Pieniny - Przyroda i Człowiek 14: 79-89.

WilczeK Z., ZARZYCKI W. (2013): Szata roślinna rezerwatu przyrody „Dolina Łańskiego Potoku” na Pogórzu Śląskim (Karpaty Zachodnie). Chrońmy Przyrodę Ojczystą 69(4): 322-329.

Wilhelm M., Rusińska A., Stebel A., Górski P., Vončina G., Fojcik B., Rosadziński S., Fudali E., SAlachna A., Zubel R. (2015): Contribution to the bryoflora of the Wolin Island (NW Poland). Steciana 19(2): 75-87.

WIŚNIEWSKA Z. (1957): Hypnum cupressiforme L. i jego odmiany w zbiorach Instytutu Botaniki UJ. Fragmenta Floristica et Geobotanica 3(1): 129-140.

Żarnowiec J., Stebel A. (2014): Mchy polskich Bieszczadów Zachodnich i Bieszczadzkiego Parku Narodowego - stan poznania, ekologia, zagrożenia. Monografie Bieszczadzkie 16.

Żarnowiec J., Stebel A., Ochyra R. (2004): Threatened moss species in the Polish Carpathians in the light of a new red-list of mosses in Poland. In: A. Stebel, R. Ochyra (eds). Bryological studies in the Western Carpathians. Sorus, Poznań: 9-28.

Żarnowiec J., SzWEd W. (2004): A contribution to the moss flora of the subalpine and alpine belts of the Babia Góra Massif (Western Carpathians). In: A. Stebel, R. Ochyra (eds). Bryological studies in the Western Carpathians. Sorus, Poznań: 101-118.

For citation (1): GóRsKi P., VONČINA G., SMOCZYK M., Klama H., Šoltés R., Wilhelm M., Rutkowska M. (2016): New distributional data on bryophytes of Poland and Slovakia, 8. Steciana 20(4): 191-200. doi: $10.12657 /$ steciana. 020.020

For citation (2): SMOCZYK M. (2016): 9. Fossombronia wondraczekii (Corda) Lindb. In: P. Górski, A Rusińska (eds). New distributional data on bryophytes of Poland and Slovakia, 8. Steciana 20(4): 121. doi: 10.12657/steciana.020.020 